\title{
Tropical convection regimes in climate models: evaluation with satellite observations
}

\author{
Andrea K. Steiner ${ }^{1,2,3}$, Bettina C. Lackner ${ }^{3}$, and Mark A. Ringer ${ }^{4}$ \\ ${ }^{1}$ Wegener Center for Climate and Global Change (WEGC), University of Graz, Graz, Austria \\ ${ }^{2}$ Institute for Geophysics, Astrophysics, and Meteorology, Institute of Physics, University of Graz, Graz, Austria \\ ${ }^{3}$ Doctoral Programme Climate Change, University of Graz, Graz, Austria \\ ${ }^{4}$ Met Office Hadley Centre, Exeter, UK
}

Correspondence: Andrea K. Steiner (andi.steiner@uni-graz.at)

Received: 18 July 2017 - Discussion started: 20 September 2017

Revised: 28 February 2018 - Accepted: 5 March 2018 - Published: 6 April 2018

\begin{abstract}
High-quality observations are powerful tools for the evaluation of climate models towards improvement and reduction of uncertainty. Particularly at low latitudes, the most uncertain aspect lies in the representation of moist convection and interaction with dynamics, where rising motion is tied to deep convection and sinking motion to dry regimes. Since humidity is closely coupled with temperature feedbacks in the tropical troposphere, a proper representation of this region is essential. Here we demonstrate the evaluation of atmospheric climate models with satellite-based observations from Global Positioning System (GPS) radio occultation (RO), which feature high vertical resolution and accuracy in the troposphere to lower stratosphere. We focus on the representation of the vertical atmospheric structure in tropical convection regimes, defined by high updraft velocity over warm surfaces, and investigate atmospheric temperature and humidity profiles. Results reveal that some models do not fully capture convection regions, particularly over land, and only partly represent strong vertical wind classes. Models show large biases in tropical mean temperature of more than $4 \mathrm{~K}$ in the tropopause region and the lower stratosphere. Reasonable agreement with observations is given in mean specific humidity in the lower to mid-troposphere. In moist convection regions, models tend to underestimate moisture by 10 to $40 \%$ over oceans, whereas in dry downdraft regions they overestimate moisture by $100 \%$. Our findings provide evidence that RO observations are a unique source of information, with a range of further atmospheric variables to be exploited, for the evaluation and advancement of nextgeneration climate models.
\end{abstract}

\section{Introduction}

A key challenge in current representations of the climate system is the modelling of the atmospheric water cycle and its coupling with circulation. Despite continuous efforts in model development, the spread in model uncertainty remains large in current climate models, especially for regional projections of the hydrological cycle and potential changes to both the frequency and intensity of extreme events (Collins et al., 2013). Possible reasons for underlying model errors are that processes and feedbacks are not well understood, not well represented, or not well constrained by observations (Knutti and Sedlacek, 2013). The Intergovernmental Panel on Climate Change (IPCC) finds differences in feedback processes to be the main reason for the spread of model uncertainty, stating in the latest world climate report: "Water vapour, lapse rate and cloud feedbacks each involve moist atmospheric processes closely linked to clouds and, in combination, produce most of the simulated climate feedback and most of its inter-model spread" (Boucher et al., 2013).

Differences in cloud feedbacks are considered to be the primary source of spread in both equilibrium and transient climate responses of the global mean surface temperature (the climate sensitivity) simulated by climate models (Dufresne and Bony, 2008). However, the contributions of water vapour and lapse rate are non-negligible, since their impact is reinforced by the mean model cloud feedback. Water vapour and temperature responses are closely coupled in the troposphere and models with a larger negative lapse rate feedback also have a larger positive water vapour feedback. The largest fractional changes in specific humidity together 
with the largest feedback contribution occur in the tropical upper troposphere (e.g., Chung et al., 2014). Most models agree that the combined net feedback from water vapour and lapse rate changes is positive (Boucher et al., 2013) with the net effect resulting in the amplification of a warming, which is largest in the tropical middle and upper troposphere. The proper representation of the tropospheric structure in climate models is of central importance since it has more impact than other regions of the atmosphere.

Particularly at low latitudes, the most uncertain aspect lies in the representation of moist convection and its interaction with large-scale dynamics, and improvements are necessary to reduce uncertainty in climate model projections (Stevens and Bony, 2013; Shepherd, 2014). This is one focus of the World Climate Research Programme (WCRP) and its grand challenge of clouds, circulation, and climate sensitivity. Bony et al. (2015) emphasize in particular to enhance the understanding of cloud feedbacks and convective organization.

The distribution of humidity is determined by many factors, including the detrainment of vapour and condensed water from convective systems and the large-scale atmospheric circulation. The relatively dry regions of large-scale descent play a major role in tropical long wave cooling, and changes in their area or changes in humidity could have a significant impact on water vapour feedback strength. Given the complexity of processes, there is a need for modelling and observational studies (Randall et al., 2007). Observations are regarded as essential for the development and evaluation of climate models. The Observations for Model Intercomparison Projects (Obs4MIPs) (Teixeira et al., 2014) were launched for the sixth phase of the WCRP Coupled Model Intercomparison Project (CMIP6) (Meehl et al., 2014; Eyring et al., 2016) aiming for better use of observations (Gleckler et al., 2011; Teixeira et al., 2014).

Satellite observations from Global Positioning System (GPS) radio occultation (RO) are available from 2001 and provide atmospheric thermodynamic variables at high vertical resolution and accuracy (e.g., Scherllin-Pirscher et al., 2017) for exploring the Earth's atmosphere, weather, and climate in the troposphere to the lower stratosphere (e.g., Anthes, 2011; Steiner et al., 2011). RO observations have significant impact on numerical weather prediction as they can be assimilated without bias correction, hence improving weather forecasts (e.g., Healy and Thépaut, 2006; Cardinali, 2009) and anchoring atmospheric reanalyses (e.g., Poli et al., 2010; Simmons et al., 2014).

A range of studies on atmospheric variability and changes (e.g., Lackner et al., 2011; Scherllin-Pirscher et al., 2012, 2014; Randel and Wu, 2014) have shown that RO is highly useful for characterizing the tropopause (Randel et al., 2003; Schmidt et al., 2004; Borsche et al., 2007; Rieckh et al., 2014) and the thermodynamic structure during intense convection including cloud top detection (Biondi et al., 2012, 2015). Also, the value of water vapour information from
RO has been demonstrated, e.g., for atmospheric dry layers (Rieckh et al., 2017) and for inferring water vapour feedback (Vergados et al., 2016). However, few studies exist on the evaluation of global climate model (GCM) data with RO; so far comparisons of geopotential height (Ao et al., 2015) and of dry temperature climatologies (Kishore et al., 2016; Schmidt et al., 2016) have been performed.

Here we demonstrate the exploitation of GPS RO observations for the evaluation of tropical convection regions in GCM data of the fifth Coupled Model Intercomparison Project (CMIP5). Rather than the usual approach of comparing observed and model climatologies at standard pressure levels (Ao et al., 2015; Kishore et al., 2016), we investigate the representation of temperature and humidity in the troposphere and lower stratosphere at highest available model resolution. We focus on the vertical structure of moist and dry regimes in the tropics and inspect their representation in models and observations.

\section{Data}

\subsection{Radio occultation observations}

GPS RO is an active limb sounding technique based on radio signals from Global Navigation System Satellites (GNSS) such as the GPS. On their way from the transmitter to a receiver on a low-Earth orbit satellite the microwave signals are refracted and retarded by the Earth's refractivity field. An occultation observation occurs if a GPS satellite sets behind (or rises from behind) the horizon and its signals are occulted by the Earth's limb from the viewpoint of the receiver. The movement of the satellites enables a vertical scanning of the troposphere and stratosphere with high vertical resolution of about $100 \mathrm{~m}$ in the lower troposphere to about $1.5 \mathrm{~km}$ in the stratosphere (Kursinski et al., 1997; Gorbunov et al., 2004) but inherent along-ray horizontal averaging. The horizontal resolution across-ray is about $1.5 \mathrm{~km}$ and the along-ray resolution ranges from about $60 \mathrm{~km}$ in the lower troposphere to about $300 \mathrm{~km}$ in the stratosphere (Melbourne et al., 1994; Kursinski et al., 1997). Observations are made globally and under essentially all weather conditions.

The basic measurement is the signal phase as function of time, which is proportional to the optical path length between the transmitter and the receiver. The traceability to fundamental time standards with precise atomic clocks enables a long-term stable and consistent data record. The RO phase and amplitude measurements together with precise and accurate information on the satellites' orbits enable the retrieval of physical and thermodynamic variables including bending angle, refractivity, pressure, geopotential height, temperature, and specific humidity.

A main advantage is the independent provision of precise altitude information and pressure information (ScherllinPirscher et al., 2017), which allows the use of thermody- 
namic profiles at different vertical coordinates, e.g., temperature at mean-sea-level altitude, at geopotential height, or at pressure levels. Furthermore, tropopause parameters are provided with high accuracy including tropopause temperature and tropopause height. The quality of RO measurements is best in the upper troposphere and lower stratosphere (UTLS). The observational uncertainty of individual temperature profiles is about $0.7 \mathrm{~K}$ in the tropopause region. Details on uncertainty estimates are given by Scherllin-Pirscher et al. (2017). RO data from different missions are highly consistent and agree within $0.2 \mathrm{~K}$ between 4 and $35 \mathrm{~km}$ for temperature (Scherllin-Pirscher et al., 2011a). The data, from bending angle to temperature, can be merged without intercalibration or homogenization if the same processing system is used (Schreiner et al., 2007; Foelsche et al., 2011; Steiner et al., 2011; Angerer et al., 2017). Available RO data products include individual profiles and gridded climatologies (e.g., Ho et al., 2012; Steiner et al., 2013).

For this study we used individual profile data from the following RO missions: CHAllenging Minisatellite Payload (CHAMP) (Wickert et al., 2001), Satélite de Aplicaciones Científicas (SAC-C) (Hajj et al., 2004), Gravity Recovery And Climate Experiment (GRACE-A) (Beyerle et al., 2005), and FORMOSAT-3/COSMIC (F3C) (Anthes et al., 2008). About 2000 globally distributed RO profiling measurements are available per day from these missions.

We used RO temperature and specific humidity profiles processed by the Wegener Center for Climate and Global Change (WEGC) with the Occultation Processing System (OPS) version 5.6 (Schwärz et al., 2016; Angerer et al., 2017), based on excess phase and orbit data (versions 2009.2650 and 2010.2640) from the University Corporation for Atmospheric Research (UCAR). In the OPS retrieval, bending angle is initialized at high altitudes with background data from the European Centre for MediumRange Weather Forecasts (ECMWF) short-range forecasts. Below $30 \mathrm{~km}$, the retrieved bending angle profiles only contain observational information from RO. The bending angle is inverted to atmospheric refractivity (proportional to air density), which depends on the thermodynamic conditions of the dry and moist atmosphere, i.e., on pressure, temperature, and water vapour pressure, given by the Smith-Weintraub formula (Smith and Weintraub, 1953; Kursinski et al., 1997) in Eq. (1):

$N(z)=k_{1} \frac{p(z)}{T(z)}+k_{2} \frac{e(z)}{T^{2}(z)}$,

where the constants are $k_{1}=77.6 \mathrm{~K} \mathrm{hPa}^{-1}$ and $k_{2}=3.73 \times$ $10^{5} \mathrm{~K}^{2} \mathrm{hPa}^{-1}, p$ is pressure (in $\mathrm{hPa}$ ), $T$ is temperature (in $\mathrm{K}$ ), and $e$ is partial pressure of water vapour (in $\mathrm{hPa}$ ). In dry air with very small to negligible moisture, as in the stratosphere, water vapour effects are essentially negligible. The second term of Eq. (1) becomes zero and dry temperature profiles can be directly retrieved from the RO data.
In the troposphere, where moisture content is higher, temperature and specific humidity are retrieved based on optimal estimation of RO and ECMWF short-range forecast profiles. The background contributes relevant information for retrieved temperature profiles only in the lower to middle troposphere, when observed RO information is used to obtain humidity.

A detailed description of the OPS retrieval is given by Schwärz et al. (2016; Appendix A therein). Differences between retrievals of RO dry-air atmospheric profiles and moist-air tropospheric profiles are discussed by ScherllinPirscher et al. (2011b). Error estimates for RO profiles from bending angle to temperature are provided by ScherllinPirscher et al. (2011a, 2017), and those for specific humidity by Kursinski et al. (1995, 1997), Steiner and Kirchengast (2005), and Kursinski and Gebhardt (2014). RO humidity quality is best at low latitudes where the moisture concentrations in the lower and middle troposphere are highest. Comparison of WEGC OPS v5.6 RO profiles with collocated radiosonde profiles from the Global Reference Upper Air Network (GRUAN) show consistency within 0.1 to $0.3 \mathrm{~g} \mathrm{~kg}^{-1}$ in specific humidity in the middle to lower tropical troposphere (Pincus et al., 2017), confirming accuracy estimates given by Kursinski and Gebhardt (2014). RO data are also useful in the upper troposphere where specific humidity is small. Rieckh et al. (2017) demonstrated that the detection of extremely dry atmospheric layers is possible with $\mathrm{RO}$ and showed agreement with data from multiple sources including, e.g., aircraft campaigns and reanalyses. Extensive validation of RO atmospheric profiles with independent observations, including radiosondes (e.g., Ladstädter et al., 2015) and satellite limb sounder data (e.g., Schwärz et al., 2016) has proved the high quality of RO variables.

\subsection{Climate model data}

For this study we used climate model data of CMIP5 (Taylor et al., 2012). Because our focus is the evaluation of atmospheric variables, we chose the Atmospheric Model Intercomparison Project (AMIP) experiments with atmosphereonly mode and prescribed sea surface temperature (SST), which are available at higher vertical resolution. We selected those models available with a 6-hourly resolution in time and at model level resolution in the vertical, at either a hybrid sigma pressure grid or a hybrid height grid. Requested model variables included air temperature (ta), specific humidity (hus), and surface pressure (ps); the latter was needed for the computation of vertical pressure levels from the hybrid pressure grid. In addition, we selected the variables nearsurface air temperature (tas) and Lagrangian tendency of air pressure or vertical velocity (wap) at the $500 \mathrm{hPa}$ level at daily resolution for classification purposes (see Sect. 3).

Eight different AMIP models were found available at 6hourly time resolution. Out of these, finally five models had available all needed variables and all necessary information 
Table 1. Information on models: model name; horizontal, vertical, and time resolution; modelling centre; and references.

\begin{tabular}{|c|c|c|c|c|c|}
\hline Model name & $\begin{array}{l}\text { Horizontal } \\
\text { resolution } \\
(\text { long } \times \text { lat })\end{array}$ & $\begin{array}{l}\text { Vertical } \\
\text { resolution } \\
\text { (no. of levels) }\end{array}$ & $\begin{array}{l}\text { Time } \\
\text { resolution } \\
\text { (h) }\end{array}$ & Modelling centre & Reference \\
\hline BCC-CSM1.1 & $\begin{array}{l}2.8125^{\circ} \times 2.8125^{\circ} \\
(128 \times 64)\end{array}$ & $\begin{array}{l}26 \text { hybrid } \\
\text { pressure }\end{array}$ & 6 hourly & $\begin{array}{l}\text { Beijing Climate Center (BCC), } \\
\text { China Meteorol. Administration }\end{array}$ & Wu et al. (2014) \\
\hline CCSM4 & $\begin{array}{l}1.25^{\circ} \times 0.95^{\circ} \\
(288 \times 192)\end{array}$ & $\begin{array}{l}26 \text { hybrid } \\
\text { pressure }\end{array}$ & 6 hourly & $\begin{array}{l}\text { National Center for Atmospheric } \\
\text { Research (NCAR) }\end{array}$ & Gent et al. (2011) \\
\hline GFDL-CM3 & $\begin{array}{l}2.5^{\circ} \times 2^{\circ} \\
(144 \times 90)\end{array}$ & $\begin{array}{l}48 \text { hybrid } \\
\text { pressure }\end{array}$ & 6 hourly & $\begin{array}{l}\text { NOAA Geophysical Fluid Dynam- } \\
\text { ics Lab (NOAA GFDL) }\end{array}$ & Griffies et al. (2011) \\
\hline HadGEM2-A & $\begin{array}{l}1.875^{\circ} \times 1.25^{\circ} \\
(192 \times 145)\end{array}$ & $\begin{array}{l}38 \text { hybrid } \\
\text { height }\end{array}$ & 6 hourly & Met Office Hadley Centre (MOHC) & $\begin{array}{l}\text { The HadGEM2 Develop- } \\
\text { ment Team (2011) }\end{array}$ \\
\hline NorESM1-M & $\begin{array}{l}2.5^{\circ} \times 1.895^{\circ} \\
(144 \times 96)\end{array}$ & $\begin{array}{l}26 \text { hybrid } \\
\text { pressure }\end{array}$ & 6 hourly & Norwegian Climate Centre (NCC) & Bentsen et al. (2013) \\
\hline
\end{tabular}

for comparison with RO observations at either altitude or pressure levels, i.e., for conversion of a hybrid sigma pressure grid to a pressure grid or for conversion of a hybrid height grid to an altitude grid. The models used in this study are listed in Table 1, including model name; information on horizontal, vertical, and time resolution; modelling centre; and respective references.

We used the following models: BCC-CSM1.1 of the Beijing Climate Center (BCC, China), CCSM4 of the National Center for Atmospheric Research (NCAR, USA), GFDL-CM3 of the National Oceanic and Atmospheric Administration Geophysical Fluid Dynamics Laboratory (NOAA/GFDL, USA), HadGEM2-A of the Met Office Hadley Centre (MOHC, UK), and NorESM1-M of the Norwegian Climate Centre (NCC, Norway). The models' horizontal resolutions range from near $1.25^{\circ} \times 0.95^{\circ}$ to $2.8125^{\circ} \times 2.8125^{\circ}$ in longitude and latitude. The number of vertical levels ranges from 26 to 48 . Three models are available at 26 levels including BCC-CSM1.1, CCSM4, and NorESM1-M. HadGEM2-A is available at 38 levels and GFDL-CM3 at 48 levels of which 15 levels are above $10 \mathrm{hPa}$ and not used in this study. For sensitivity tests we used in addition daily values of the HadGEM2-A model at a coarser vertical resolution with eight pressure levels only.

In addition, we used surface data of the ECMWF reanalysis (ERA-Interim) (Dee et al., 2011) at $1.5^{\circ} \times 1.5^{\circ}$ resolution in longitude and latitude with 6-hourly resolution, which is also reasonable for temporal collocation. Surface temperature and vertical velocity at $500 \mathrm{hPa}$ from ERA-Interim were needed for the classification in updraft and downdraft regions (see Sect. 3). The reanalysis was taken as proxy for classifying the observations because these variables are not provided by RO. The land-sea mask from ERA-Interim is used for classification of all data sets over land and sea areas. ERAInterim has a high horizontal resolution so that the spatial deviation when collocating to RO tangent point locations is negligible.

\section{Method}

We investigate the representation of the vertical atmospheric structure in tropical moist and dry regimes in climate models with respect to collocated RO observations based on temperature and specific humidity profiles. In our methodological approach we therefore performed first a collocation of profiles and a systematic classification of different meteorological regimes. The study region was limited to the tropics within $20^{\circ} \mathrm{S}$ to $20^{\circ} \mathrm{N}$. In the vertical we focused on the troposphere to the lower stratosphere region from about 850 to $10 \mathrm{hPa}$, where RO observations have the best quality. Temporal constraints are given on the one hand by the RO observations, which are continuously available since May 2001, with an increase in measurements since 2006 due to the F3C constellation, and on the other hand by AMIP model data, which are provided only until December 2008. The inspected time period is thus May 2001 to December 2008.

\subsection{Collocation of observations and model data}

It is important to match the location and time of the day of updraft and downdraft occurrences in order to compare for the same conditions in observations and atmospheric models with prescribed SST. All available RO profiles for the defined time period and region were selected. The time and location information of each individual RO profile, i.e., longitude and latitude of the mean tangent point location and time of the RO event, was stored for collocation with model data. The collocation procedure was based on a nearest-neighbour approach. The collocated model grid point closest in space with respect to an $\mathrm{RO}$ event was calculated as the minimum absolute difference in degree latitude between latitude of the model grid point and latitude of the RO event and as the minimum absolute difference in degree longitude between longitude of the model grid point and longitude of the RO event. Colocation in time was assigned within a time window of plus/minus $3 \mathrm{~h}$ according to the 6-hourly model resolution. The collocated model grid point closest in time to an 
RO event was chosen as the absolute minimum difference between the model time and the RO event time. To ensure a correct collocation in time, the different calendars of the models need to be taken into account, as some models use 360 days per year (BCC-CSM1.1, CCSM4, NorESM1-M), 365 days per year (HadGEM2-A), or a standard calendar (GFDLCM3). Collocated temperature and specific humidity profiles were extracted from RO and from the models at the specific locations. In addition, ERA-Interim 6-hourly data of surface temperature and vertical velocity at $500 \mathrm{hPa}$ were collocated and sampled at the RO event locations. The reanalysis data were only used as proxy for classification of the observations because these variables are not provided by RO.

In the vertical, the comparisons of model versus observation were performed at pressure levels and at altitude levels. In order to compare with models that were available at hybrid pressure levels (see Table 1), we converted those to pressure levels. We used 24 levels from 1000 to $10 \mathrm{hPa}$, including the 17 pressure levels as defined by the World Meteorological Organization plus additional levels in the tropopause region. The HadGEM2-A model data were available at 38 hybrid height levels and the comparison was performed at a meansea-level altitude grid from $100 \mathrm{~m}$ to $33 \mathrm{~km}$. The latter enabled us to perform a comparison at high vertical resolution. In addition we compared to HadGEM2-A at a very coarse vertical resolution with only eight pressure levels for testing the sensitivity to the vertical resolution.

\subsection{Classification of dynamical regimes}

The classification of dynamical regimes is based on the fact that regions of rising motion (upper-level divergence) are closely tied to regions of deep convection, whereas regions of sinking motion (convergence) represent mean clear-sky conditions (Lau et al., 1997). In regions of large-scale ascending motions, optically thick convective clouds occur over the warmest ocean waters, e.g., the western Pacific warm pool or the eastern Indian Ocean, having strong effects in both the shortwave and long-wave parts of the spectrum, with large reductions of outgoing long-wave radiation (OLR) and large increases in the shortwave reflection to space. Areas of subsidence are associated with both clear-sky conditions and areas of low-level boundary layer cloud, which form over cooler SSTs, e.g., the equatorial Pacific cold tongue. The low-level cloud has a strong shortwave cooling effect but only a weak long-wave effect (e.g., Ringer and Allan, 2004).

According to Bony et al. (1997) pressure vertical velocity at $500 \mathrm{hPa}\left(\omega_{500}\right)$ is a good proxy for the large-scale vertical motion (ascending-descending air) associated with the large-scale tropical circulation. In the tropics, the $\omega_{500}$ is proportional to the $200 \mathrm{hPa}$ divergence and to the $850 \mathrm{hPa}$ convergence. It corresponds to the change in pressure $p$ with time $t, \omega=\mathrm{d} p / \mathrm{d} t$, with rising motions corresponding to negative values of $\omega_{500}$ whereas sinking motions correspond to positive values of $\omega_{500}$. The occurrence of large-scale rising motion is furthermore strongly coupled with SST larger than about 26 to $27^{\circ} \mathrm{C}$. For SST less than about 26 to $27^{\circ} \mathrm{C}$, one finds sinking motions over the tropical oceans with low-level cloudiness over this region (Bony et al., 1997; Ringer and Allan, 2004). According to Ringer and Allan (2004), higher SSTs of larger than $26.5^{\circ} \mathrm{C}$ are associated with a wide range of vertical velocities from strongest ascent to strongest descent, whereas lower SSTs of less than $26.5^{\circ} \mathrm{C}$ are primarily associated with strong descent or only very weak vertical motion.

In this study we therefore classify dynamical regimes of large-scale atmospheric motion in terms of vertical motion $\omega_{500}$ and near-surface air temperature $\left(T_{2} \mathrm{~m}\right)$. The regimes range from strong ascent defined by $\omega_{500}<-40 \mathrm{hPa} \mathrm{day}^{-1}$ to strong descent defined by $\omega_{500}>40 \mathrm{hPa}$ day $^{-1}$ and from coolest waters to warmest waters with the boundary between the two regimes defined at $T_{2} \mathrm{~m}$ of $26^{\circ} \mathrm{C}$. The $\omega_{500}$ classes range from -160 to $+160 \mathrm{hPa}$ day $^{-1}$ with class intervals of $20 \mathrm{hPa}$ day $^{-1}$. The $T_{2} \mathrm{~m}$ classes range from 17.5 to $32.5^{\circ} \mathrm{C}$ with class intervals of $1^{\circ} \mathrm{C}$. In addition, a distinction between regions over land and over oceans is made. Ocean or land was assigned first, then data were classified with respect to $\omega_{500}$ and $T_{2 \mathrm{~m}}$ (after Ringer and Allan, 2004).

According to the defined classifications, we sorted and sampled RO profiles and model profiles over the period May 2001 to December 2008 on a daily basis. For the RO data, the respective classes were defined using the ERAInterim dynamical fields $\left(\omega_{500}, T_{2}\right.$; not available from RO) as proxy. Information on daily mean $\omega_{500}$ values and $T_{2} \mathrm{~m}$ was extracted from ERA-Interim at the RO locations. RO temperature and humidity profiles were then sampled into the respective classes. This provides information on the distribution of updraft and downdraft regimes in the observations. For the model data, classes were assigned using each model's own dynamical fields $\left(\omega_{500}, T_{2} \mathrm{~m}\right)$. Information on daily mean $\omega_{500}$ and $T_{2} \mathrm{~m}$ from the models was extracted at (collocated) RO locations. Model temperature and humidity profiles were then sampled into the respective classes. After sampling temperature and humidity profiles in updraft and downdraft regimes, a detailed evaluation of the occurrence distributions in models and observations was performed and differences in models with respect to the observations were investigated.

Figure 1 shows the representation of tropical convection regions in observations (ERA-Interim) and in two exemplary models, HadGEM2-A and CCSM4 (at the locations of RO observations), in the form of Hovmöller diagrams. Convection regions are denoted by updraft (negative $\omega_{500}$ in blue) and found in ERA-Interim (Fig. 1a) from 30 to $90^{\circ} \mathrm{W}$ over Amazonia, from 0 to $30^{\circ}$ E over equatorial Africa, and largest from 60 to $180^{\circ} \mathrm{E}$ over Indonesia from the eastern Indian ocean to the western Pacific, corresponding to regions of low OLR. Non-convection regions denoted by sinking motion (positive $\omega_{500}$ in red) are found over the eastern Pacific and Atlantic regions, corresponding to regions of high OLR. 

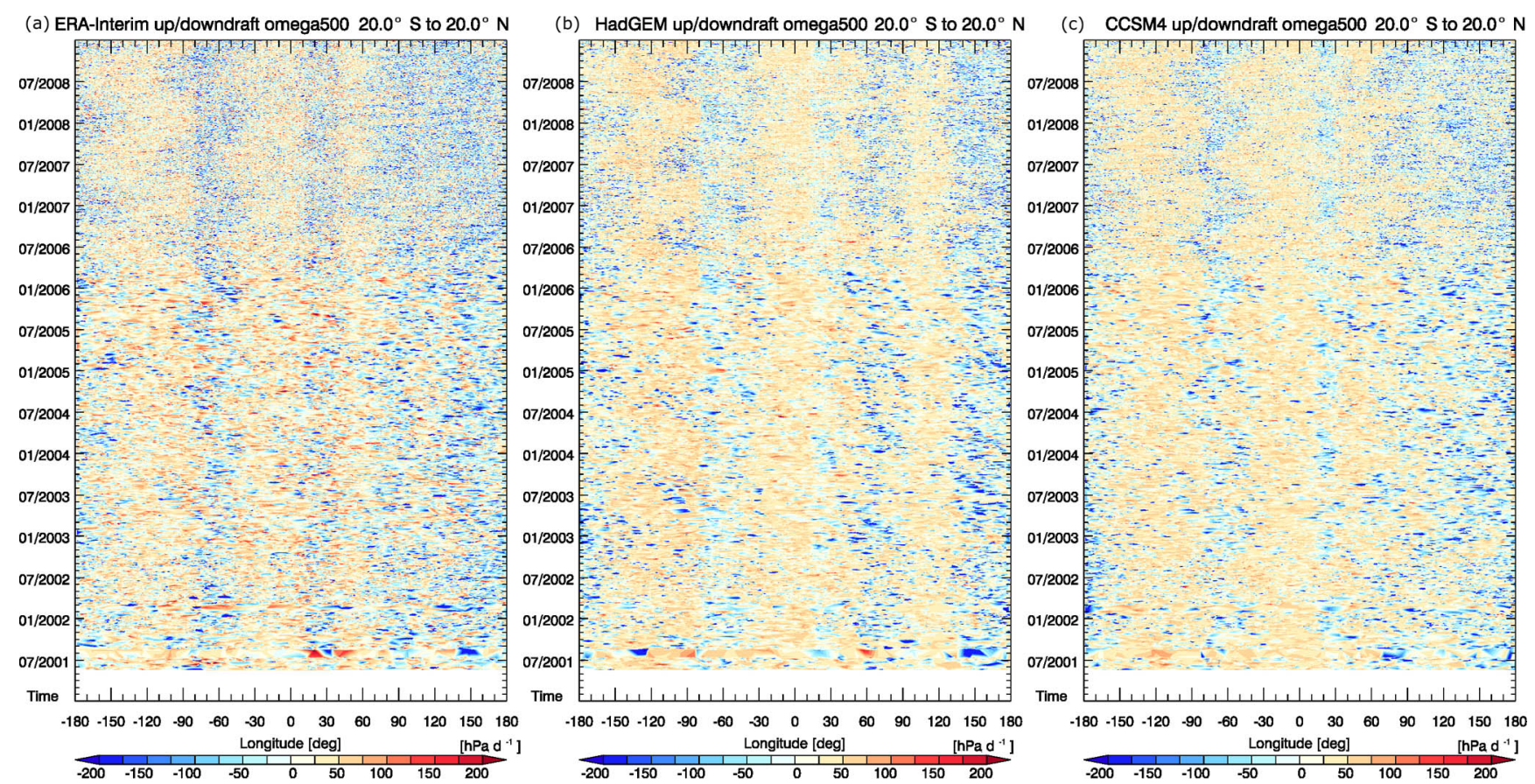

Figure 1. Tropical convection regions represented as function of time versus longitude in ERA-Interim as proxy for the observations (a), the HadGEM2-A model (b), and the CCSM4 model (c), shown for co-locations with RO observations getting denser in 2006. Updraft (blue) denotes convection regions and downdraft (red) denotes non-convection regions.

Comparing the representation of the respective regions, we find that some models do not fully capture convection regions, e.g., HadGEM2-A shows a gap between 90 to $130^{\circ} \mathrm{E}$ over Indonesia (Fig. 1b) and GFDL_CM3 over Africa (not shown), while others such as CCSM4 (Fig. 1c) are in better agreement with ERA-Interim. Such differences may be related to the representation of tropical variability phenomena, e.g., the simulation of the 30-day to 60-day (Madden-Julian) equatorial oscillation.

An overview on the distribution of $\omega_{500}$ and $T_{2} \mathrm{~m}$ in ERAInterim and in the different models is presented in Fig. 2. Most models show a narrower distribution in $\omega_{500}$ than ERAInterim, underestimating velocities near $\pm 50 \mathrm{hPa} \mathrm{day}^{-1}$ (except for HadGEM2-A) and overestimating small velocities near $\pm 20 \mathrm{hPa} \mathrm{day}^{-1}$ (Fig. 2a). This feature is found to be more distinct over the ocean (Fig. 2c) but is also seen over land (Fig. 2e). An exception is the BCC_CSM1.1 model, which shows a similar form of the distribution as ERAInterim but is shifted towards higher velocities. For the temperature distributions quite good agreement is found in models with respect to ERA-Interim (Fig. 2b), especially over sea (Fig. 2d). This most likely results from the prescription of observed SST as boundary condition in the AMIP simulations. A slight shift is seen in the GFDL_CM3 model and the BCC_CSM1.1 model towards higher temperatures, particularly over land (Fig. 2f). There, the temperature distribution in GFDL_CM3 is shifted by about 1 to $2{ }^{\circ} \mathrm{C}$ and BCC_CSM1.1 shows a smoother and broader tempera- ture distribution than other models, thereby underestimating mean temperatures and overestimating higher temperatures above $26^{\circ} \mathrm{C}$.

\section{Results and discussion}

The distribution of atmospheric profiles from RO observations and from five different models into vertical velocity classes and temperature classes is detailed in Fig. 3. More than 400000 collocated profiles are found in total over sea and land (Fig. 3a) of which about $80 \%$ are distributed over sea (Fig. 3b) and about $20 \%$ over land (Fig. 3c). RO observations show a slightly lower number of occultations over land with $19.6 \%$ compared to the models ranging from 20.7 to $22.1 \%$.

Different distribution patterns are found for models compared to the observations over sea and over land. While RO observations are mainly clustered (more than 3000 profiles per class) in vertical velocity from -60 to $80 \mathrm{hPa} \mathrm{day}^{-1}$ and from 23 to $28^{\circ} \mathrm{C}$ over sea, the models show a more narrow distribution in vertical velocity from -20 to $60 \mathrm{hPa} \mathrm{day}^{-1}$ but a broader distribution in temperature from 21 to $29^{\circ} \mathrm{C}$. The models are missing profiles in updraft classes of $<-20 \mathrm{hPa} \mathrm{day}^{-1}$ between 24 and $26^{\circ} \mathrm{C}$. Also, classes above $80 \mathrm{hPaday}^{-1}$ in vertical velocity are hardly occupied by model profiles. For BCC_CSM1.1 the profile distribution over sea is a bit more similar to the observations than that 


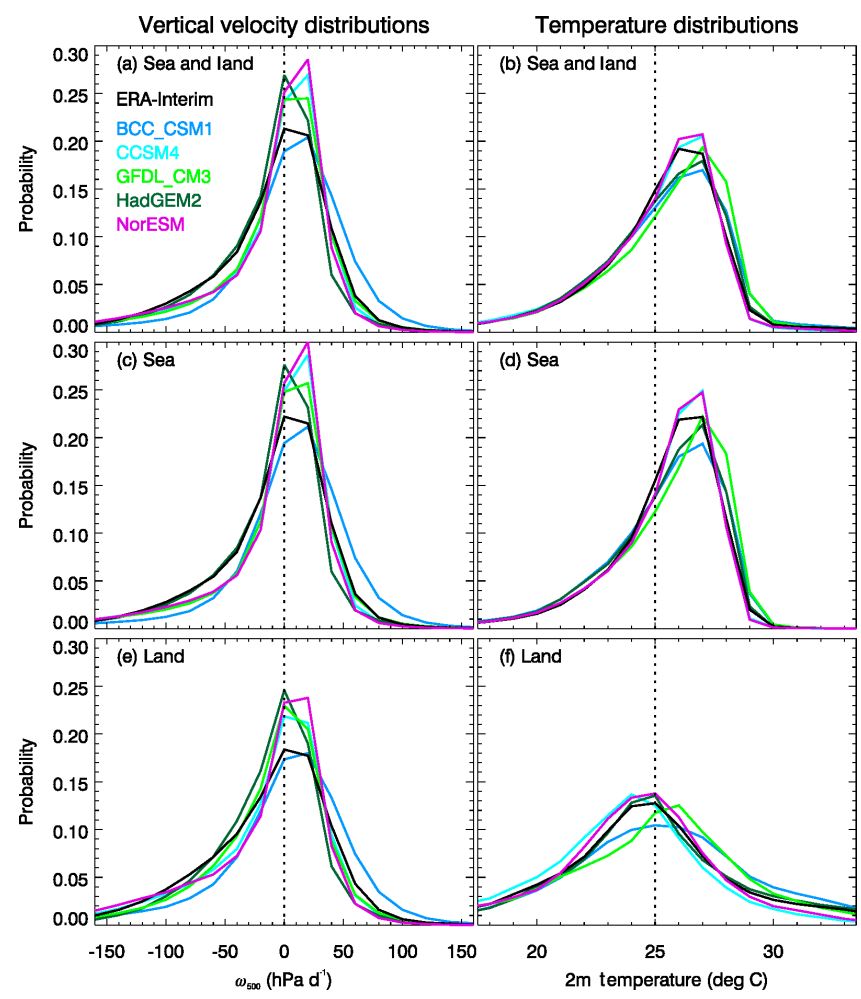

Figure 2. Distribution of vertical velocity $\omega_{500}$ (left) and nearsurface temperature $T_{2 \mathrm{~m}}$ (right) in the tropics over sea and land (a, b), over sea only (c, d), and over land (e, f), shown for ERA-Interim as proxy for the observations (black) and for five climate models (coloured).

of the other models, although classes of large updraft and high surface temperature $\left(<-40 \mathrm{hPa} \mathrm{day}^{-1}\right.$ and $\left.>25^{\circ} \mathrm{C}\right)$ are hardly occupied. In general, the results are consistent with the findings of Ringer and Allan (2004) that lower temperatures $\left(\mathrm{SST}<26^{\circ} \mathrm{C}\right)$ are associated with only weak vertical motion or strong descent.

Over land the distributions are quite different. RO profiles are clustered in classes between $\pm 40 \mathrm{hPa} \mathrm{day}^{-1}$ and from 22 to $27^{\circ} \mathrm{C}$, whereas model profiles are broader distributed in temperature classes from 21 to $29^{\circ} \mathrm{C}$ with the maximum occurrence shifted to higher temperatures of 25 to $26^{\circ} \mathrm{C}$. Note that using data with varying vertical velocity and nearsurface temperatures, e.g., other observational data sets or reanalyses, might give a slightly different sampling of the observed RO profiles. However, this is negligible as for this study setup it is only important to match location and time of observations and models in order to compare for the same conditions.

\subsection{Climatological differences between models and observations in the tropics}

Having sampled atmospheric profiles into the respective updraft and downdraft classes, we inspected the differences be- tween temperature profiles and humidity profiles in models with respect to the RO observations. We computed the mean temperature profile and mean humidity profile of each class for models and observations, respectively, and then the difference profiles of model minus RO. In a first test we investigated different model resolutions.

We compared the HadGEM2-A model at a coarse vertical resolution using four pressure levels only $(250,100,50$, $10 \mathrm{hPa}$ ) (Fig. 4a). The overall mean difference in (dry) temperature (see Sect. 2.1) between HadGEM2-A and RO shows a warm bias of the model of about $3.5 \mathrm{~K}$ at $100 \mathrm{hPa}$ and of $2.2 \mathrm{~K}$ at $50 \mathrm{hPa}$ in the stratosphere, whereas a cold bias of $-1 \mathrm{~K}$ is seen at $250 \mathrm{hPa}$ in the troposphere. These biases are consistent with those shown by Hardiman et al. (2015). In particular, the UTLS biases are long-standing issues in the Hadley Centre model, including HadGEM2 shown here, and have been considerably reduced in the most recent version (HadGEM3) (see Williams et al., 2018, their Fig. 8), which will be submitted for CMIP6. Noticeable is the large standard deviation in the tropopause region. We further compared to HadGEM2-A at a (4 times) higher vertical resolution using 16 altitude levels (Fig. 4b) and found very much the same picture regarding the bias but a much smaller variance.

Comparing (physical) temperatures (see Sect. 2.1) shows consistent results (Fig. 4c), which is expected as physical temperatures are identical to dry temperature in a dry atmosphere, i.e., in the upper troposphere to lower stratosphere (see Sect. 2.1). Mean temperature differences show that HadGEM2-A is about $-1 \mathrm{~K}$ colder than RO in the troposphere. It is about $4 \mathrm{~K}$ warmer in the tropopause region and about $2 \mathrm{~K}$ warmer in the lower stratosphere region. Inspecting absolute temperature profiles and the respective vertical temperature gradients (Fig. 4d) reveals that the differences stem from a sharper representation of the tropopause in the observations and from larger temperature gradients in the upper troposphere and in the lower stratosphere (Fig. 4d), which the model does not capture. The results furthermore indicate that a higher resolution does not help to reduce the large model bias in the tropopause region but to reduce variance.

In the following evaluations we use the highest available vertical model resolution and compare at two different vertical grids (see Sect. 2.2). We compare the HadGEM2-A model at altitude and the other models at pressure levels to RO. Figure 5 presents absolute temperature profiles and difference profiles between model and observations. The mean absolute temperature over all classes provides a representation of the climatological mean temperature in the tropics. It decreases from $290 \mathrm{~K}$ near $850 \mathrm{hPa}$ to about $195 \mathrm{~K}$ in the tropopause and increases to $230 \mathrm{~K}$ near $10 \mathrm{hPa}$. In the troposphere, performance is best for NorESM-M and also for CCSM4 and GFDL_CM3, whereas BCC_CMS1.1 shows a large negative bias of up to $-3 \mathrm{~K}$ near $250 \mathrm{hPa}$ and HadGEM2-A a constant bias of $-1 \mathrm{~K}$ with respect to RO. Large temperature differences are revealed in the tropopause region for all inspected models, ranging from $-4.5 \mathrm{~K}$ in 


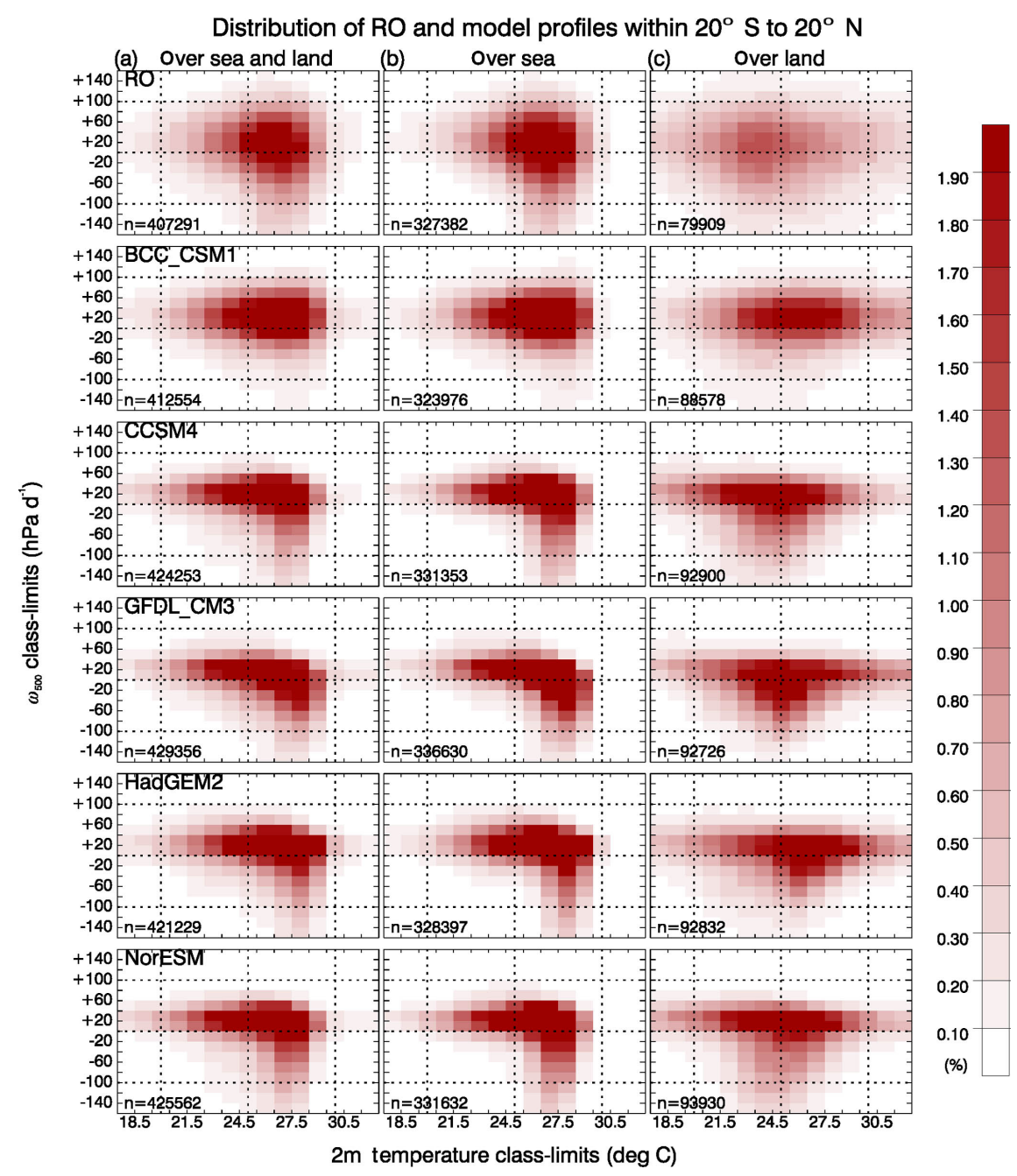

Figure 3. Data distribution in vertical velocity classes $\omega_{500}$ and near-surface temperature classes $T_{2} \mathrm{~m}$ over sea and land (a), over sea (b), and over land (c) shown for RO observations and five climate models: BCC-CSM1.1, CCSM4, GFDL-CM3, HadGEM2-A, and NorESM1-M (top to bottom). For better perception, the gridded lines mark temperatures of $(20,25,30)^{\circ} \mathrm{C}$ and $\omega_{500}$ at $(-100,0,100) \mathrm{hPa}$ day ${ }^{-1}$.

CCSM4 to $4.4 \mathrm{~K}$ in HadGEM2-A. In comparison the maximum difference between $\mathrm{RO}$ and ERA-Interim is about $-1 \mathrm{~K}$ in the tropopause region and less than $0.5 \mathrm{~K}$ in the troposphere and lower stratosphere, which stems from known biases in ERA-Interim (Poli et al. 2010).

In the lower stratosphere, most models are too warm, with biases of 2 to $4 \mathrm{~K}$. This is again consistent with Hardiman et al. (2015) and also with Kim et al. (2013), both of whom evaluated climate models against reanalysis temperatures. The results of differences in tropical temperature climatology agree with findings of Kishore et al. (2016, Fig. 3a therein), who also used GPS RO data. However, our analysis indicates that the tropopause is not well captured in models. The large differences possibly result from the representation of the tropopause at specific model levels, in BCC_CSM1.1 at $70 \mathrm{hPa}$, in CCSM4 at $80 \mathrm{hPa}$, in GFDL_CM3 at $100 \mathrm{hPa}$, and in NorESM1-M at $70 \mathrm{hPa}$. Furthermore, temperature gradi- ents in models differ from those in the RO observations in the upper troposphere and the lower stratosphere. Note that Hardiman et al. (2015) have suggested that model biases in the height of the tropopause might be related to the dipole in the temperature bias between the upper troposphere and lower stratosphere. Clearly this is an area where the RO measurements should potentially be of great use, especially as the vertical resolution of models increases and the ability to resolve the UTLS temperature gradients improves.

For humidity profiles (Fig. 6) quite good agreement is given in tropical mean specific humidity. BCC-CSM1.1 agrees well with RO. CCSM4, GFDL_CM3, and NorESM$M$ show a positive humidity bias of 10 to $20 \%$ and HadGEM2-A a negative humidity bias of 10 to $20 \%$ in the lower to middle troposphere. Differences get larger in the upper troposphere where the amount of humidity is very low. RO specific humidity profiles show larger variance across the 

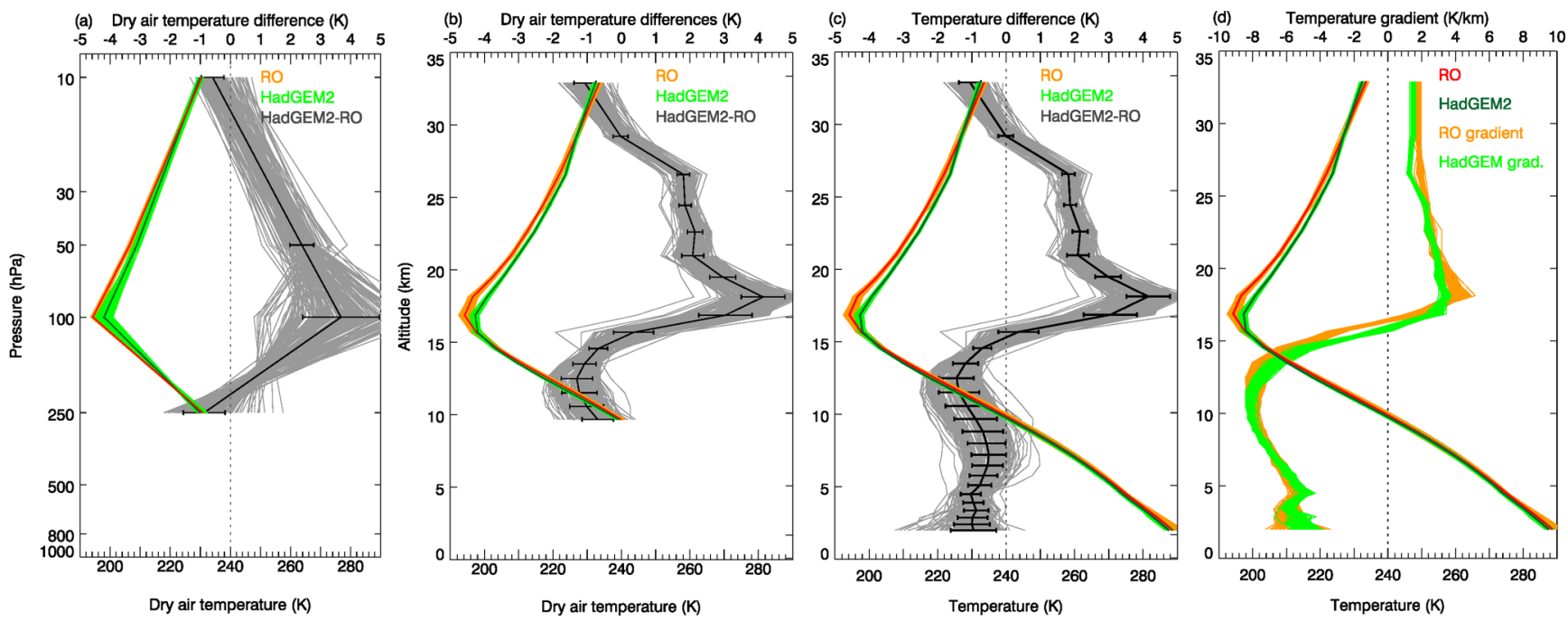

Figure 4. Comparison of HadGEM2-A model data to RO observations for all classes $\left(\omega_{500}\right.$ and $\left.T_{2} \mathrm{~m}\right)$ in the tropics in terms of collocated temperature profiles and temperature difference profiles of HadGEM2-A minus RO (lower axes depict absolute values, upper axes differences to RO). Shown are dry temperature (see Sect. 2.1) at coarse vertical resolution for four pressure levels (a), dry temperature at high vertical resolution for altitude levels (b), and physical temperature at high vertical resolution (c) and corresponding temperature gradients (d).
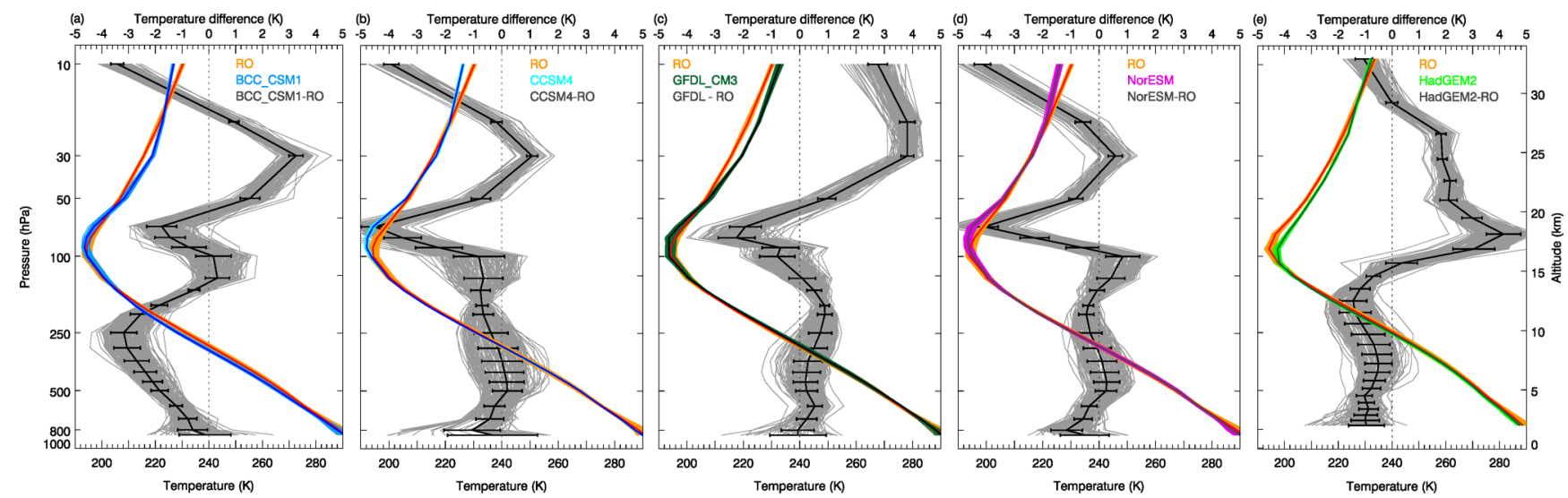

Figure 5. Temperature difference of model data minus RO observations (upper axes) and collocated temperature profiles (lower axes) for all classes $\left(\omega_{500}\right.$ and $\left.T_{2} \mathrm{~m}\right)$ in the tropics, shown for BCC-CSM1.1 (a), CCSM4 (b), GFDL-CM3 (c), and NorESM1-M (d) at pressure levels and for HadGEM2-A (e) at corresponding altitude levels. Mean and standard deviation of the differences are indicated in black.

classes while the models do not show such a large spread in humidity.

\subsection{Humidity differences in convection regions and non-convection regions}

A separate evaluation of convection regions and nonconvection region was performed in order to gain a better understanding of the differences seen in humidity in these selected regions. Convection regions with strong updraft were defined by $\omega_{500}<-40 \mathrm{hPa} \mathrm{day}^{-1}$ and $T_{2 \mathrm{~m}}>26^{\circ} \mathrm{C}$ corresponding to classes in the lower right part of Fig. $3 \mathrm{a}$. Non-convection regions with strong downdraft were defined by $\omega_{500}>40 \mathrm{hPaday}^{-1}$ and $T_{2} \mathrm{~m}<26^{\circ} \mathrm{C}$, corresponding to classes in the upper left part of Fig. 3a. All classes falling into the specified regions were selected.

Specific humidity is found about 2 to 3 times larger in convection regions than in non-convection regions, particularly over sea. Specific humidity in the specified convection region ranges from about $17(14) \mathrm{g} \mathrm{kg}^{-1}$ at $1000 \mathrm{hPa}$, $10(8.8) \mathrm{g} \mathrm{kg}^{-1}$ at $800 \mathrm{hPa}, 3(2.5) \mathrm{g} \mathrm{kg}^{-1}$ at $500 \mathrm{hPa}$, to 0.07 (0.05) $\mathrm{g} \mathrm{kg}^{-1}$ at $200 \mathrm{hPa}$ over the ocean (over land).

Figure 7 shows the respective classified humidity profiles in convection regions (Fig. 7a) and in non-convection regions (Fig. 7b) separately over sea (left subpanels) and over land (right subpanels) for each model (top to bottom). For specific humidity in convection regions (Fig. 7a) quite reasonable agreement between models and observations is found 

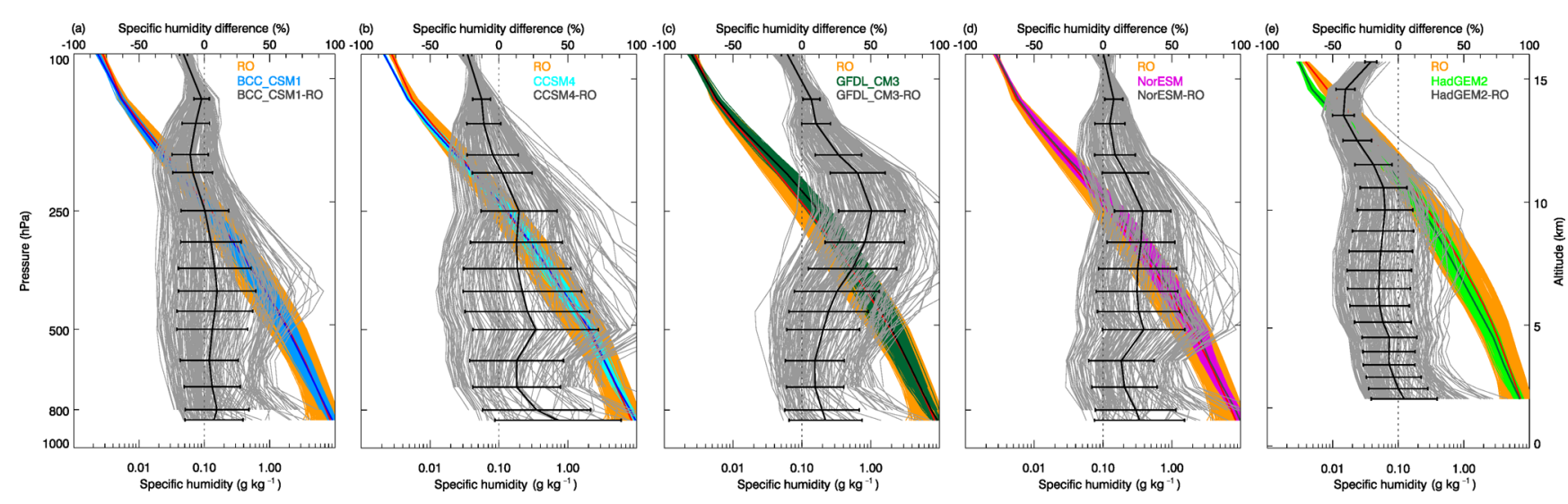

Figure 6. Specific humidity difference of model data minus RO observations (upper axes) and collocated specific humidity profiles (lower axes) for all classes $\left(\omega_{500}\right.$ and $\left.T_{2} \mathrm{~m}\right)$ in the tropics, shown for BCC-CSM1.1 (a), CCSM4 (b), GFDL-CM3 (c), and NorESM1-M (d) at pressure levels and for HadGEM2-A (e) at corresponding altitude levels. Mean and standard deviation of the differences are indicated in black. Note the different $y$ axis compared to Fig. 5 for temperature.

and the variance is small. Over land, the agreement is best with mean differences of 10 to $20 \%$, except for GFDL_CM3. In convection regions over the ocean, most models tend to underestimate moisture by 10 to $40 \%$. NorESM1-M shows the best performance in representation of specific humidity, while GFDL_CM3 shows a large bias near $250 \mathrm{hPa}$.

In non-convection regions (Fig. 7b) the amount of humidity over sea is much smaller and thus the spread in differences is larger. Best agreement with observations is given over land for three models: BCC-CSM1.1, CCSM4, and NorESM1M. HadGEM2-A is about $25 \%$ too dry, and GFDL is too moist near $250 \mathrm{hPa}$. The largest differences are found in non-convection regions over the ocean, where all models are found too moist and overestimate specific humidity by $100 \%$. This result is consistent with findings by Kursinski and Gebhard (2014), showing that models have shortcomings in representing dry extremes.

\section{Summary, conclusions, and outlook}

Tropical convection regimes in CMIP5 atmospheric climate models were evaluated with satellite-based observations from Global Positioning System (GPS) radio occultation (RO), which feature high vertical resolution and accuracy in the upper troposphere to lower stratosphere. Focusing on moist and dry regimes in the tropics, we investigated the representation of these regimes in models with respect to the observations. We inspected the vertical atmospheric structure based on temperature and specific humidity in the troposphere and lower stratosphere using five AMIP models available with high resolution in the vertical (model levels) and in time (6-hourly), including BCC-CSM1.1 (BCC, China), CCSM4 (NCAR, USA), GFDL-CM3 (NOAA/GFDL, USA), HadGEM2-A (MOHC, UK), and NorESM1-M (NCC, Norway). Comparison with GPS RO was carried out for different vertical resolutions and different vertical grids, at pressure levels as well as altitude levels.

We performed a systematic classification of moist updraft and dry downdraft regimes based on pressure vertical velocity at $500 \mathrm{hPa}\left(\omega_{500}\right)$ and near-surface air temperature $\left(T_{2} \mathrm{~m}\right)$, since regions of rising motion over warm surfaces are tied to deep convection and regions of sinking motion over cooler surfaces are tied to dry regimes. ERA-Interim was used as proxy for defining classes in the observations, which range from regimes of strong ascent $\left(\omega_{500}<-40 \mathrm{hPa} \mathrm{day}^{-1}\right.$ and $\left.T_{2 \mathrm{~m}}>26^{\circ} \mathrm{C}\right)$ to regimes of strong descent $\left(\omega_{500}>40 \mathrm{hPa} \mathrm{day}^{-1}\right.$ and $\left.T_{2 \mathrm{~m}}<26^{\circ} \mathrm{C}\right)$. According to the defined classifications, collocated model profiles and RO profiles were sorted and sampled over the period May 2001 to December 2008 on a daily basis. Computation of differences in collocated profiles made deviations between models and observations apparent.

Regarding the representation of updraft and downdraft regions over longitude, we found that not all models fully capture updraft, e.g., HadGEM2-A shows a gap over Indonesia and GFDL_CM3 over Africa, while other models are in better agreement with ERA-Interim. Most models underestimate higher vertical velocities near $\pm 50 \mathrm{hPa} \mathrm{day}^{-1}$ (except for HadGEM2-A) but overestimate low vertical velocities near $\pm 20 \mathrm{hPaday}^{-1}$. Surface temperature distributions are in quite good agreement with ERA-Interim, which is most likely due to the prescription of observed SST as boundary condition in the AMIP models. However, particularly over land, some models (BCC_CSM1.1, GFDL_CM3) show a shift to higher surface temperatures.

Over sea, atmospheric profiles of RO observations are clustered from -60 to $80 \mathrm{hPaday}^{-1}$ in vertical velocity and from 23 to $28^{\circ} \mathrm{C}$ in surface temperature. Model profiles are clustered over a narrower pressure range from -20 to $60 \mathrm{hPaday}^{-1}$ but over a broader tempera- 
(a) Convection region
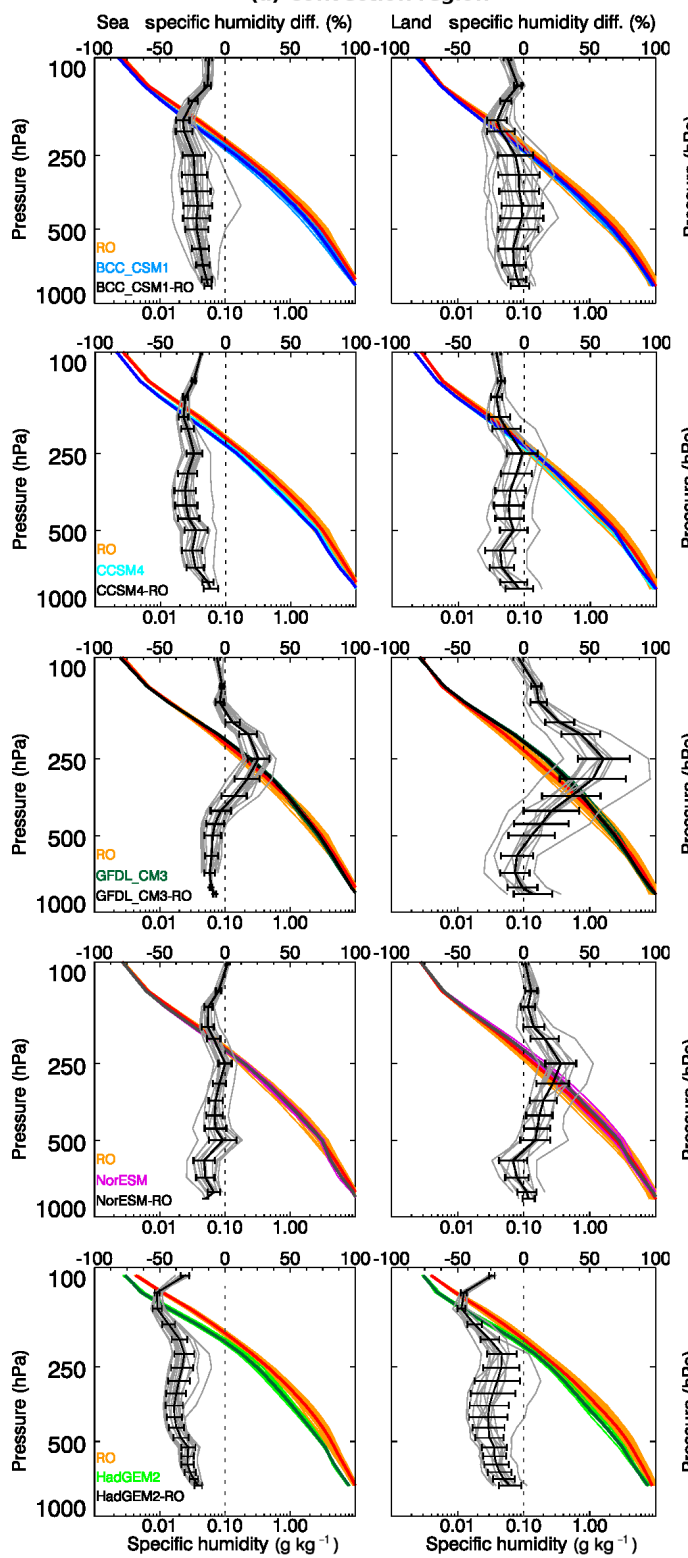
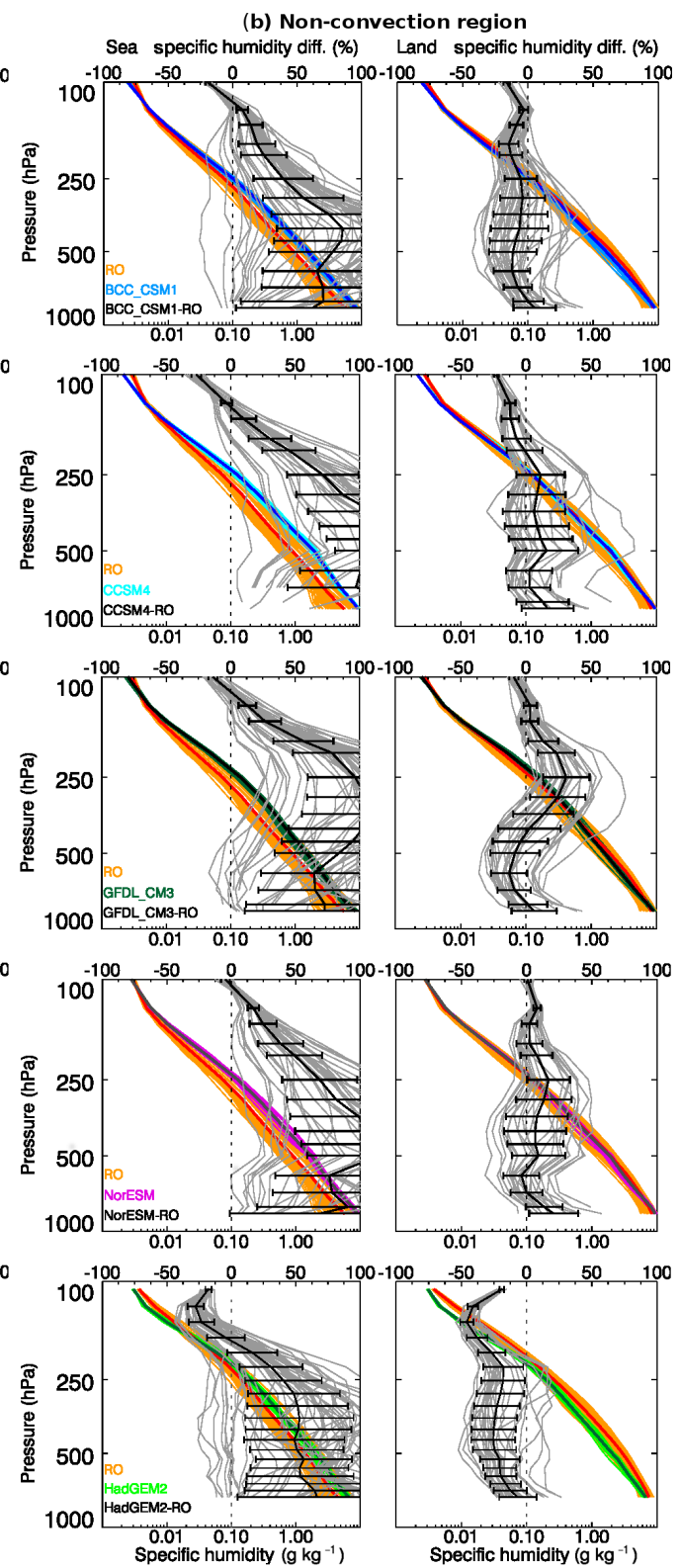

Figure 7. Specific humidity difference of model data minus RO observations (upper axes) and collocated specific humidity profiles (lower axes) for BCC-CSM1.1, CCSM4, GFDL-CM3, NorESM1-M, and HadGEM2 (top to bottom), shown for convection regions (a) over sea (left) and over land (right) and for non-convection regions (b) over sea (left) and over land (right). Mean and standard deviation of the differences are indicated in black.

ture range from 21 to $29^{\circ} \mathrm{C}$. Updraft classes with higher velocities $\left(<-20 \mathrm{hPaday}^{-1}\right)$ over lower surface temperatures and downdraft classes with high vertical velocities $\left(>80 \mathrm{hPa} \mathrm{day}^{-1}\right)$ are hardly occupied in models in contrast to the observations. Over land, the distribution of RO and model profiles is quite different. RO profiles are clustered in classes between $\pm 40 \mathrm{hPa}$ day $^{-1}$ and from 22 to $27^{\circ} \mathrm{C}$, whereas model profiles are broader distributed over surface temperature and shifted to higher temperatures.
Mean temperature differences between models and observations in the tropics show quite good agreement of about $1 \mathrm{~K}$ in the troposphere (with exceptions) but large model biases are revealed in the tropopause region reaching more than $4 \mathrm{~K}$. Also in the lower stratosphere, most models exhibit a warm bias of 2 to $4 \mathrm{~K}$. These results show that the tropopause region is not well captured in models, which is due to the little variability in tropopause height in models defined on standard pressure levels and too small temperature gradients in the tropopause region and the lower stratosphere (compared 
to sharp tropopause structures and steeper temperature gradients in RO). For humidity in the tropics we found reasonable agreement with differences of 10 to $20 \%$ in mean specific humidity in the lower to middle troposphere.

Inspecting convection regions, where the amount of humidity is large, we found reasonable agreement between models and observations in the lower to middle troposphere over land. Over the oceans most models underestimate moisture. Specific humidity differences of about only $10 \%$ are found for NorESM1-M, whereas BCC-CSM1.1, CCSM4, and HadGEM 2 are about 20 to $40 \%$ too dry over sea during convection and GFDL_CM3 shows a large moist bias above $500 \mathrm{hPa}$.

In non-convection regions, the amount of humidity over sea is much smaller and the spread in differences is found larger. Over land, most models agree well, with observations within about $10 \%$, except HadGEM2-A is about $25 \%$ too dry. Largest differences are found in non-convection regions over sea where almost all models are too wet and overestimate observed moisture by $100 \%$. This appears reasonable as some climate models do not capture the really extreme dry events and therefore appear positively biased in nonconvective regions.

Our results provide evidence of the value of RO observations for model evaluation in the troposphere to lower stratosphere as we demonstrated for temperature and specific humidity. RO delivers vertically high resolved temperature profiles for inspecting the thermal structure in models which might be particularly useful for improving the models' representation of the tropopause region. Humidity information from $\mathrm{RO}$ in the tropical troposphere is valuable for identifying biases in models as shown here for the case of convection and non-convection regimes. A number of dynamical, microphysical, and radiative processes influence the simulation of both the tropical tropopause temperature and the lowerstratospheric water vapour in climate models (Hardiman et al., 2015) and the RO observations provide a valuable source of information to help evaluate and improve their representation.

RO data are available as individual profiles and gridded climatological fields. The latter are commonly available in the form of monthly mean zonal-mean climatologies for the whole RO record. From 2006 onward, the data amount is large enough for a finer gridding because data from more than a single RO satellite are available. These data from multiple RO satellites facilitate the provision of daily climatologies of $2.5^{\circ} \times 2.5^{\circ}$ in latitude and longitude, which can be obtained by weighted averaging in space and time. The use of such higher resolved daily RO climatological fields has been demonstrated only recently for the investigation of atmospheric blocking (see Brunner et al., 2016; Brunner and Steiner, 2017).

A range of further atmospheric variables is available from $\mathrm{RO}$, such as bending angle, refractivity, density, tropopause temperature, and tropopause altitude. The advantage of RO lies in the high vertical resolution, high accuracy and precision, global availability, and virtually independent information on altitude and thermodynamic atmospheric variables, which can be used at different vertical coordinate systems including mean-sea-level altitude, geopotential height, pressure, or potential temperature (Scherllin-Pirscher et al., 2017).

This enables evaluating models not only at standard pressure levels as currently foreseen in Obs4MIPs but at best possible model resolution, thus exploiting RO observations for specified comparison tasks as stated by Notz (2015): "climate models can only meaningfully be evaluated relative to a specific purpose". A possible way could be to perform model evaluation in observational space, e.g., bending angle space, by converting model information with a forward model operator and thereby making use of the full information content of RO measurements independently of retrieved variables. Work is currently underway to include RO forward models in the GCM satellite simulator COSP (Bodas-Salcedo et al., 2011).

The RO community (http://www.irowg.org) is making RO observations from several processing centres available for Obs4MIPs. This is a common undertaking within the project Radio Occultation based gridded CLIMate data sets (ROCLIM) in the World Meteorological Organization's program on Sustained, Coordinated Processing of Environmental Satellite data for Climate Monitoring (SCOPE-CM) (http: //www.scope-cm.org/projects/scm-08/).

In the near future several new RO missions are planned like the COSMIC-2 constellation as well as the use of signals from several GNSS, e.g., the Chinese BeiDou system, the European Galileo, and Russian GLONASS systems. Thus the number of occultation observations is expected to largely increase in the next years. This will enhance the importance of RO as a unique observational data set and as a new source of information for evaluation, development, and testing of the next generation of climate models.

Data availability. The climate model data used in this study are publicly available from the CMIP5 database of the Program for Climate Model Diagnosis and Intercomparison (PCMDI) established at the Lawrence Livermore National Laboratory (LLNL) and can be accessed via https://esgf-node.llnl.gov/search/cmip5/. ERAInterim data used in this study are publicly available from ECMWF (Reading, UK) and can be accessed via https://www.ecmwf.int/ en/forecasts/datasets/reanalysis-datasets/era-interim. The WEGC OPSv5.6 RO data are available on request from Andrea K. Steiner and will be made publicly available in 2018 .

Author contributions. AKS performed the main data analyses, produced the graphics, and wrote the manuscript. BCL wrote basic programming code, performed initial analyses, and contributed to the manuscript. MAR provided guidance on study design and model aspects and contributed to finalizing the manuscript. 
Competing interests. The authors declare that they have no conflict of interest.

Acknowledgements. We are grateful to Gottfried Kirchengast (WEGC, AT) for initial ideas for this study and a range of further inputs and valuable discussions in the course of the work. Barbara Scherllin-Pirscher (WEGC, AT) is thanked for many fruitful discussions and helpful comments. Martin W. Jury (WEGC, AT) is thanked for help with model data collection. We are grateful to the UCAR/CDAAC (Boulder, CO, USA) for the provision of level 1a RO data and ECMWF (Reading, UK) for access to its reanalysis, analysis, and short-term forecast data. We thank the WEGC processing team members, especially Marc Schwärz and Florian Ladstädter (WEGC, AT), for OPSv5.6 RO data. We acknowledge the World Climate Research Programme's Working Group on Coupled Modelling, which is responsible for CMIP, and we thank the climate modelling groups (listed in Table 1 of this paper) for producing and making available their model output. For CMIP, the US Department of Energy's Program for Climate Model Diagnosis and Intercomparison provided coordinating support and led development of software infrastructure in partnership with the Global Organization for Earth System Science Portals. ECMWF (Reading, UK) is acknowledged for access to its ERA-Interim data set. This work was funded by the Austrian Science Fund (FWF) under research grants P21642-N21 (TRENDEVAL) and P27724-NBL (VERTICLIM).

Edited by: Gabriele Stiller

Reviewed by: two anonymous referees

\section{References}

Angerer, B., Ladstädter, F., Scherllin-Pirscher, B., Schwärz, M., Steiner, A. K., Foelsche, U., and Kirchengast, G.: Quality aspects of the Wegener Center multi-satellite GPS radio occultation record OPSv5.6, Atmos. Meas. Tech., 10, 4845-4863, https://doi.org/10.5194/amt-10-4845-2017, 2017.

Anthes, R. A.: Exploring Earth's atmosphere with radio occultation: contributions to weather, climate and space weather, Atmos. Meas. Tech., 4, 1077-1103, https://doi.org/10.5194/amt-4-10772011, 2011.

Anthes, R. A., Ector, D., Hunt, D. C., Kuo, Y.-H., Rocken, C., Schreiner, W. S., Sokolovskiy, S. V., Syndergaard, S., Wee, T.K., Zeng, Z., Bernhardt, P. A., Dymond, K. F., Chen, Y., Liu, H., Manning, K., Randel, W. J., Trenberth, K. E., Cucurull, L., Healy, S. B., Ho, S.-P., McCormick, C., Meehan, T. K., Thompson, D. C., and Yen, N. L.: The COSMIC/FORMOSAT3 Mission: Early Results, B. Am. Meteorol. Soc., 89, 313-333, https://doi.org/10.1175/BAMS-89-3-313, 2008.

Ao, C. O., Jiang, J. H., Mannucci, A. J., Su, H., Verkhoglyadova, O., Zhai, C., Cole, J., Donner, L., Iversen, T., Morcrette, C., Rotstayn, L., Watanabe, M., and Yukimoto, S.: Evaluation of CMIP5 upper troposphere and lower stratosphere geopotential height with GPS radio occultation observations, J. Geophys. Res.-Atmos., 120, 1678-1689, https://doi.org/10.1002/2014JD022239, 2015.
Bentsen, M., Bethke, I., Debernard, J. B., Iversen, T., Kirkevåg, A., Seland, Ø., Drange, H., Roelandt, C., Seierstad, I. A., Hoose, C., and Kristjánsson, J. E.: The Norwegian Earth System Model, NorESM1-M - Part 1: Description and basic evaluation of the physical climate, Geosci. Model Dev., 6, 687-720, https://doi.org/10.5194/gmd-6-687-2013, 2013.

Beyerle, G., Schmidt, T., Michalak, G., Heise, S., Wickert, J., and Reigber, C.: GPS radio occultation with GRACE: Atmospheric profiling utilizing the zero difference technique, Geophys. Res. Lett., 32, L13806, https://doi.org/10.1029/2005GL023109, 2005.

Biondi, R., Randel, W. J., Ho, S.-P., Neubert, T., and Syndergaard, S.: Thermal structure of intense convective clouds derived from GPS radio occultations, Atmos. Chem. Phys., 12, 5309-5318, https://doi.org/10.5194/acp-12-5309-2012, 2012.

Biondi, R., Steiner, A. K., Kirchengast, G., and Rieckh, T.: Characterization of thermal structure and conditions for overshooting of tropical and extratropical cyclones with GPS radio occultation, Atmos. Chem. Phys., 15, 5181-5193, https://doi.org/10.5194/acp-15-5181-2015, 2015.

Bodas-Salcedo, A., Webb, M. J., Bony, S., Chepfer, H., Dufresne, J.-L., Klein, S. A., Zhang, Y., Marchand, R., Haynes, J. M., Pincus, R., and John, V. O.: COSP: Satellite simulation software for model assessment, B. Am. Meteorol. Soc., 92, 1023-1043, https://doi.org/10.1175/2011BAMS2856.1, 2011.

Bony, S., Lau, K.-M., and Sud, Y. C.: Sea Surface Temperature and Large-Scale Circulation Influences on Tropical Greenhouse Effect and Cloud Radiative Forcing, J. Climate, 10, 2055-2077, https://doi.org/10.1175/15200442(1997)010<2055:SSTALS>2.0.CO;2, 1997.

Bony, S., Stevens, B., Frierson, D. M. W., Jakob, C., Kageyama, M., Pincus, R., Shepherd, T. G., Sherwood, S. C., Siebesma, A. P., Sobel, A. H., Watanabe, M., and Webb, M. J.: Clouds, circulation and climate sensitivity, Nat. Geosci., 8, 261-268, 2015.

Borsche, M., Kirchengast, G., and Foelsche, U.: Tropical tropopause climatology as observed with radio occultation measurements from CHAMP compared to ECMWF and NCEP analyses, Geophys. Res. Lett, 34, L03702, https://doi.org/10.1029/2006GL027918, 2007.

Boucher, O., Randall, D., Artaxo, P., Bretherton, C., Feingold, G., Forster, P., Kerminen, V.-M., Kondo, Y., Liao, H., Lohmann, U., Rasch, P., Satheesh, S. K., Sherwood, S., Stevens, B., and Zhang, X. Y.: Clouds and Aerosols, in: Climate Change 2013: The Physical Science Basis. Contribution of Working Group I to the Fifth Assessment Report of the Intergovernmental Panel on Climate Change, edited by: Stocker, T. F., Quin, D., Plattner, G.-K., Tignor, M., Allen, S. K., Boschung, J., Nauels, A., Xia, Y., Bex, V., and Midgley, P. M., Cambridge University Press, Cambridge, UK and New York, NY, USA, 2013.

Brunner, L. and Steiner, A. K.: A global perspective on atmospheric blocking using GPS radio occultation - one decade of observations, Atmos. Meas. Tech., 10, 4727-4745, https://doi.org/10.5194/amt-10-4727-2017, 2017.

Brunner, L., Steiner, A. K., Scherllin-Pirscher, B., and Jury, M. W.: Exploring atmospheric blocking with GPS radio occultation observations, Atmos. Chem. Phys., 16, 4593-4604, https://doi.org/10.5194/acp-16-4593-2016, 2016.

Cardinali, C.: Monitoring the observation impact on the shortrange forecast, Q. J. Roy. Meteor. Soc, 135, 239-250, https://doi.org/10.1002/qj.366, 2009. 
Chung, E.-S., Soden, B., Sohn, B. J., and Shi, L.: Uppertropospheric moistening in response to anthropogenic warming, P. Natl. Acad. Sci. USA, 111, 11636-11641, https://doi.org/10.1073/pnas.1409659111, 2014.

Collins, M., Knutti, R., Arblaster, J., Dufresne, J.-L., Fichefet, T., Friedlingstein, P., Gao, X., Gutowski, W. J., Johns, T., Krinner, G. , Shongwe, M., Tebaldi, C., Weaver, A. J., and Wehner, M,.: Long-term Climate Change: Projections, Com-mitments and Irreversibility, in: Climate Change 2013: The Physical Science Basis. Contribution of Working Group I to the Fifth Assessment Report of the Intergovernmental Panel on Climate Change, edited by: Stocker, T. F., Quin, D., Plattner, G.-K., Tignor, M., Allen, S. K., Boschung, J., Nauels, A., Xia, Y., Bex, V., and Midgley, P. M., Cambridge University Press, Cambridge, UK and New York, NY, USA, 2013.

Dee, D. P., Uppala, S. M., Simmons, A. J., Berrisford, P., Poli, P., Kobayashi, S., Andrae, U., Balmaseda, M. A., Balsamo, G., Bauer, P., Bechtold, P., Beljaars, A. C. M., van de Berg, L., Bidlot, J., Bormann, N., Delsol, C., Dragani, R., Fuentes, M., Geer, A. J., Haimberger, L., Healy, S. B., Hersbach, H., Hólm, E. V., Isaksen, L., Kållberg, P., Köhler, M., Matricardi, M., McNally, A. P., Monge-Sanz, B. M., Morcrette, J.-J., Park, B.-K., Peubey, C., de Rosnay, P., Tavolato, C., Thépaut, J.-N., and Vitart, F.: The ERA-Interim reanalysis: configuration and performance of the data assimilation system, Q. J. Roy. Meteor. Soc., 137, 553-597, https://doi.org/10.1002/qj.828, 2011.

Dufresne, J.-L. and Bony, S.: An Assessment of the Primary Sources of Spread of Global Warming Estimates from Coupled Atmosphere-Ocean Models, J. Climate, 21, 5135-5144, https://doi.org/10.1175/2008JCLI2239.1, 2008.

Eyring, V., Bony, S., Meehl, G. A., Senior, C. A., Stevens, B., Stouffer, R. J., and Taylor, K. E.: Overview of the Coupled Model Intercomparison Project Phase 6 (CMIP6) experimental design and organization, Geosci. Model Dev., 9, 1937-1958, https://doi.org/10.5194/gmd-9-1937-2016, 2016.

Foelsche, U., Scherllin-Pirscher, B., Ladstädter, F., Steiner, A. K., and Kirchengast, G.: Refractivity and temperature climate records from multiple radio occultation satellites consistent within $0.05 \%$, Atmos. Meas. Tech., 4, 2007-2018, https://doi.org/10.5194/amt-4-2007-2011, 2011.

Gent, P. R., Danabasoglu, G., Donner, L. J., Holland, M. M., Hunke, E. C., Jayne, S. R., Lawrence, D. M., Neale, R. B., Rasch, P. J., Vertenstein, M., Worley, P. H., Yang, Z.-L., and Zhang, M.: The Community Climate System Model Version 4, J. Climate, 24, 4973-4991, https://doi.org/10.1175/2011JCLI4083.1, 2011.

Gleckler, P., Ferraro, R., and Waliser, D.: Improving use of satellite data in evaluating climate models, Eos Trans. AGU, 92, 172-172, https://doi.org/10.1029/2011EO200005, 2011.

Gorbunov, M. E., Benzon, H.-H., Jensen, A. S., Lohmann, M. S., and Nielsen, A. S.: Comparative analysis of radio occultation processing approaches based on Fourier integral operators, Radio Sci., 39, RS6004, https://doi.org/10.1029/2003RS002916, 2004.

Griffies, S. M., Winton, M., Donner, L. J., Horowitz, L. W., Downes, S. M., Farneti, R., Gnanadesikan, A., Hurlin, W. J., Lee, H.-C., Liang, Z., Palter, J. B., Samuels, B. L., Wittenberg, A. T., Wyman, B. L., Yin, J., and Zadeh, N.: The GFDL CM3 Coupled Climate Model: Characteristics of the Ocean and Sea Ice Simulations, J. Climate, 24, 3520-3544, https://doi.org/10.1175/2011JCLI3964.1, 2011.
Hajj, G. A., Ao, C. O., Iijima, B. A., Kuang, D., Kursinski, E. R., Mannucci, A. J., Meehan, T. K., Romans, L. J., de la Torre Juarez, M., and Yunck, T. P.: CHAMP and SAC-C atmospheric occultation results and intercomparisons, J. Geophys. Res., 109, D06109, https://doi.org/10.1029/2003JD003909, 2004.

Hardiman, S. C., Boutle, I. A., Bushell, A. C., Butchart, N., Cullen, M. J. P., Field, P. R., Furtado, K., Manners, J. C., Milton, S. F., Morcrette, C., O'Connor, F. M., Shipway, B. J., Smith, C., Walters, D. N., Willett, M. R., Williams, K. D., Wood, N., Abraham, N. L., Keeble, J., Maycock, A. C., Thuburn, J., and Woodhouse, M. T.: Processes Controlling Tropical Tropopause Temperature and Stratospheric Water Vapor in Climate Models, J. Climate, 28, 6516-6535, https://doi.org/10.1175/JCLI-D-15-0075.1, 2015.

Healy, S. B. and Thépaut, J.-N.: Assimilation experiments with CHAMP GPS radio occultation measurements, Q. J. Roy. Meteor. Soc., 132, 605-623, https://doi.org/10.1256/qj.04.182, 2006.

Ho, S., Hunt, D., Steiner, A. K., Mannucci, A. J., Kirchengast, G., Gleisner, H., Heise, S., von Engeln, A., Marquardt, C., Sokolovskiy, S., Schreiner, W., Scherllin-Pirscher, B., Ao, C., Wickert, J., Syndergaard, S., Lauritsen, K. B., Leroy, S., Kursinski, E. R., Kuo, Y.-H., Foelsche, U., Schmidt, T., and Gorbunov, M.: Reproducibility of GPS radio occultation data for climate monitoring: Profile-to-profile inter-comparison of CHAMP climate records 2002 to 2008 from six data centers, J. Geophys. Res., 117, D18111, https://doi.org/10.1029/2012JD017665, 2012.

Kim, J., Grise, K. M., and Son, S.-W.: Thermal characteristics of the cold-point tropopause region in CMIP5 models, J. Geophys. Res.-Atmos., 118, 8827-8841, https://doi.org/10.1002/jgrd.50649, 2013.

Kishore, P., Basha, G., Venkat Ratnam, M., Velicogna, I., Ouarda, T. B. M. J., and Narayana Rao, D.: Evaluating CMIP5 models using GPS radio occultation COSMIC temperature in UTLS region during 2006-2013: twenty-first century projection and trends, Clim. Dynam., 47, 3253-3270, https://doi.org/10.1007/s00382016-3024-8, 2016.

Knutti, R. and Sedlacek, J.: Robustness and uncertainties in the new CMIP5 climate model projections, Nature Clim. Change, 3, 369373, https://doi.org/10.1038/nclimate1716, 2013.

Kursinski, E. R. and Gebhardt, T.: A Method to Deconvolve Errors in GPS RO-Derived Water Vapor Histograms, J. Atmos. Ocean. Tech., 31, 2606-2628, https://doi.org/10.1175/JTECHD-13-00233.1, 2014.

Kursinski, E. R., Hajj, G. A., Hardy, K. R., Romans, L. J., and Schofield, J. T.: Observing tropospheric water vapor by radio occultation using the Global Positioning System, Geophys. Res. Lett., 22, 2365-2368, https://doi.org/10.1029/95GL02127, 1995.

Kursinski, E. R., Hajj, G. A., Schofield, J. T., Linfield, R. P., and Hardy, K. R.: Observing Earth's atmosphere with radio occultation measurements using the Global Positioning System, J. Geophys. Res, 102, 23429-23465, https://doi.org/10.1029/97JD01569, 1997.

Lackner, B. C., Steiner, A. K., Kirchengast, G., and Hegerl, G. C.: Atmospheric Climate Change Detection by Radio Occultation Data Using a Fingerprinting Method, J. Climate, 24, 5275-5291, https://doi.org/10.1175/2011JCLI3966.1, 2011.

Ladstädter, F., Steiner, A. K., Schwärz, M., and Kirchengast, G.: Climate intercomparison of GPS radio occultation, RS90/92 ra- 
diosondes and GRUAN from 2002 to 2013, Atmos. Meas. Tech., 8, 1819-1834, https://doi.org/10.5194/amt-8-1819-2015, 2015.

Lau, K.-M., Wu, H.-T., and Bony, S.: The Role of LargeScale Atmospheric Circulation in the Relationship between Tropical Convection and Sea Surface Temperature, J. Climate, 10, 381-392, https://doi.org/10.1175/15200442(1997)010<0381:TROLSA>2.0.CO;2, 1997.

Meehl, G. A., Moss, R., Taylor, K. E., Eyring, V., Stouffer, R. J., Bony, S., and Stevens, B.: Climate Model Intercomparisons: Preparing for the Next Phase, Eos Trans. AGU, 95, 77-78, https://doi.org/10.1002/2014EO090001, 2014.

Melbourne, W. G., Davis, E. S., Duncan, C. B., Hajj, G. A., Hardy, K. R., Kursinski, E. R., Meehan, T. K., Young, L. E., and Yunck, T. P.: The application of spaceborne GPS to atmospheric limb sounding and global change monitoring, JPL Publication 94-18, 147 pp., Jet Propulsion Lab, Pasadena, CA, USA, 1994.

Notz, D.: How well must climate models agree with observations?, Philos. T. R. Soc. A, 373, 20140164, https://doi.org/10.1098/rsta.2014.0164, 2015.

Pincus, R., Beljaars, A., Buehler, S. A., Kirchengast, G., Ladstaedter, F., and Whitaker, J. S.: The Representation of Tropospheric Water Vapor Over Low-Latitude Oceans in (Re-)analysis: Errors, Impacts, and the Ability to Exploit Current and Prospective Observations, Surv. Geophys., 38, 1399-1423, https://doi.org/10.1007/s10712-017-9437-z, 2017.

Poli, P., Healy, S. B., and Dee, D. P.: Assimilation of Global Positioning System radio occultation data in the ECMWF ERAInterim reanalysis, Q. J. Roy. Meteor. Soc., 136, 1972-1990, https://doi.org/10.1002/qj.722, 2010.

Randall, D. A., Wood, R. A., Bony, S., Colman, R., Fichefet, T., Fyfe, J., Kattsov, V., Pitman, A., Shukla, J., Srinivasan, J., Stouffer, R. J., Sumi, A., and Taylor, K. E.: Climate Models and Their Evaluation, in: Climate Change 2007: The Physical Science Basis. Contribution of Working Group I to the Fourth Assessment Report of the Intergovernmental Panel on Climate Change, edited by: Solomon, S., Qin, D., Manning, M., Chen, Z., Marquis, M., Averyt, K. B., Tignor, M., and Miller, H. L., Cambridge University Press, Cambridge, UK and New York, NY, USA, 2007.

Randel, W. J. and Wu, F.: Variability of Zonal Mean Tropical Temperatures Derived from a Decade of GPS Radio Occultation Data, J. Atmos. Sci., 72, 1261-1275, https://doi.org/10.1175/JAS-D-14-0216.1, 2014.

Randel, W. J., Wu, F., and Rivera Ríos, W.: Thermal variability of the tropical tropopause region derived from GPS/MET observations, J. Geophys. Res., 108, 4024, https://doi.org/10.1029/2002JD002595, 2003.

Rieckh, T., Scherllin-Pirscher, B., Ladstädter, F., and Foelsche, U.: Characteristics of tropopause parameters as observed with GPS radio occultation, Atmos. Meas. Tech., 7, 3947-3958, https://doi.org/10.5194/amt-7-3947-2014, 2014.

Rieckh, T., Anthes, R., Randel, W., Ho, S.-P., and Foelsche, U.: Tropospheric dry layers in the tropical western Pacific: comparisons of GPS radio occultation with multiple data sets, Atmos. Meas. Tech., 10, 1093-1110, https://doi.org/10.5194/amt10-1093-2017, 2017.

Ringer, M. A. and Allan, R. P.: Evaluating climate model simulations of tropical cloud, Tellus A, 56, 308-327, https://doi.org/10.1111/j.1600-0870.2004.00061.x, 2004.
Scherllin-Pirscher, B., Steiner, A. K., Kirchengast, G., Kuo, Y.-H., and Foelsche, U.: Empirical analysis and modeling of errors of atmospheric profiles from GPS radio occultation, Atmos. Meas. Tech., 4, 1875-1890, https://doi.org/10.5194/amt-4-1875-2011, $2011 \mathrm{a}$.

Scherllin-Pirscher, B., Kirchengast, G., Steiner, A. K., Kuo, Y.-H., and Foelsche, U.: Quantifying uncertainty in climatological fields from GPS radio occultation: an empiricalanalytical error model, Atmos. Meas. Tech., 4, 2019-2034, https://doi.org/10.5194/amt-4-2019-2011, 2011 b.

Scherllin-Pirscher, B., Deser, C., Ho, S.-P., Chou, C., Randel, W., and Kuo, Y.-H.: The vertical and spatial structure of ENSO in the upper troposphere and lower stratosphere from GPS radio occultation measurements, Geophys. Res. Lett., 39, L20801, https://doi.org/10.1029/2012GL053071, 2012.

Scherllin-Pirscher, B., Steiner, A. K., and Kirchengast, G.: Deriving dynamics from GPS radio occultation: Three-dimensional wind fields for monitoring the climate, Geophys. Res. Lett., 41, 73677374, https://doi.org/10.1002/2014GL061524, 2014.

Scherllin-Pirscher, B., Steiner, A. K., Kirchengast, G., Schwärz, M., and Leroy, S. S.: The power of vertical geolocation of atmospheric profiles from GNSS radio occultation, J. Geophys. Res.-Atmos., 122, 1595-1616, https://doi.org/10.1002/2016JD025902, 2017.

Schmidt, T., Wickert, J., Beyerle, G., and Reigber, C.: Tropical tropopause parameters derived from GPS radio occultation measurements with CHAMP, J. Geophys. Res., 109, D13105, https://doi.org/10.1029/2004JD004566, 2004.

Schmidt, T., Schoon, L., Dobslaw, H., Matthes, K., Thomas, M., and Wickert, J.: UTLS temperature validation of MPI-ESM decadal hindcast experiments with GPS radio occultations, Meteorol. Z., 25, 673-683, https://doi.org/10.1127/metz/2015/0601, 2016.

Schreiner, W., Rocken, C., Sokolovkiy, S., Syndergaard, S., and Hunt, D. C.: Estimates of the precision of GPS radio occultations from the COSMIC/FORMOSAT-3 mission, Geophys. Res. Lett, 34, L04808, https://doi.org/10.1029/2006GL027557, 2007.

Schwärz, M., Kirchengast, G., Scherllin-Pirscher, B., Schwarz, J., Ladstädter, F., and Angerer, B.: Multi-mission validation by satellite radio occultation extension project - Final report, Tech. Rep. for ESA/ESRIN No. 01/2016, Wegener Center, University of Graz, Graz, Austria, available at: https://wegcwww.uni-graz.at/publ/wegcpubl/arsclisys/2016/ Schwaerz-etal_MMValRO-FinRep_Dec2016.pdf (last access: 29 March 2018), 2016.

Shepherd, T. G.: Atmospheric circulation as a source of uncertainty in climate change projections, Nat. Geosci., 7, 703-708, 2014.

Simmons, A. J., Poli, P., Dee, D. P., Berrisford, P., Hersbach, H., Kobayashi, S., and Peubey, C.: Estimating lowfrequency variability and trends in atmospheric temperature using ERA-Interim, Q. J. Roy. Meteor. Soc., 140, 329-353, https://doi.org/10.1002/qj.2317, 2014.

Smith, E. and Weintraub S.: The constants in the equation for atmospheric refractive index at radio frequencies, P. IRE, 41, 10351037, 1953.

Steiner, A. K. and Kirchengast, G.: Error analysis for GNSS radio occultation data based on ensembles of profiles from end-to-end simulations, J. Geophys. Res, 110, D15307, https://doi.org/10.1029/2004JD005251, 2005. 
Steiner, A. K., Lackner, B. C., Ladstädter, F., Scherllin-Pirscher, B., Foelsche, U., and Kirchengast, G.: GPS radio occultation for climate monitoring and change detection, Radio Sci., 46, RS0D24, https://doi.org/10.1029/2010RS004614, 2011.

Steiner, A. K., Hunt, D., Ho, S.-P., Kirchengast, G., Mannucci, A. J., Scherllin-Pirscher, B., Gleisner, H., von Engeln, A., Schmidt, T., Ao, C., Leroy, S. S., Kursinski, E. R., Foelsche, U., Gorbunov, M., Heise, S., Kuo, Y.-H., Lauritsen, K. B., Marquardt, C., Rocken, C., Schreiner, W., Sokolovskiy, S., Syndergaard, S., and Wickert, J.: Quantification of structural uncertainty in climate data records from GPS radio occultation, Atmos. Chem. Phys., 13, 1469-1484, https://doi.org/10.5194/acp13-1469-2013, 2013.

Stevens, B. and Bony, S.: What Are Climate Models Missing?, Science, 340, 1053-1054, https://doi.org/10.1126/science.1237554, 2013.

Taylor, K. E., Stouffer, R. J., and Meehl, G. A.: An Overview of CMIP5 and the Experiment Design, B. Am. Meteorol. Soc., 93, 485-498, https://doi.org/10.1175/BAMS-D-11-00094.1, 2012.

Teixeira, J., Waliser, D., Ferraro, R., Gleckler, P., Lee, T., and Potter, G.: Satellite Observations for CMIP5: The Genesis of Obs4MIPs, B. Am. Meteorol. Soc., 95, 1329-1334, https://doi.org/10.1175/BAMS-D-12-00204.1, 2014.

The HadGEM2 Development Team: Martin, G. M., Bellouin, N., Collins, W. J., Culverwell, I. D., Halloran, P. R., Hardiman, S. C., Hinton, T. J., Jones, C. D., McDonald, R. E., McLaren, A. J., O'Connor, F. M., Roberts, M. J., Rodriguez, J. M., Woodward, S., Best, M. J., Brooks, M. E., Brown, A. R., Butchart, N., Dearden, C., Derbyshire, S. H., Dharssi, I., Doutriaux-Boucher, M., Edwards, J. M., Falloon, P. D., Gedney, N., Gray, L. J., Hewitt, H. T., Hobson, M., Huddleston, M. R., Hughes, J., Ineson, S., Ingram, W. J., James, P. M., Johns, T. C., Johnson, C. E., Jones, A., Jones, C. P., Joshi, M. M., Keen, A. B., Liddicoat, S., Lock, A. P., Maidens, A. V., Manners, J. C., Milton, S. F., Rae, J. G. L., Ridley, J. K., Sellar, A., Senior, C. A., Totterdell, I. J., Verhoef, A., Vidale, P. L., and Wiltshire, A.: The HadGEM2 family of Met Office Unified Model climate configurations, Geosci. Model Dev., 4, 723-757, https://doi.org/10.5194/gmd-4-723-2011, 2011.
Vergados, P., Mannucci, A. J., Ao, C. O., and Fetzer, E. J.: Using GPS radio occultations to infer the water vapor feedback, Geophys. Res. Lett., 43, 11841-11851, https://doi.org/10.1002/2016GL071017, 2016.

Wickert, J., Reigber, C., Beyerle, G., König, R., Marquardt, C., Schmidt, T., Grunwaldt, L., Galas, R., Meehan, T. K., Melbourne, W. G., and Hocke, K.: Atmosphere sounding by GPS radio occultation: First results from CHAMP, Geophys. Res. Lett, 28, 3263, https://doi.org/10.1029/2001GL013117, 2001.

Williams, K. D., Copsey, D., Blockley, E. W., Bodas-Salcedo, A., Calvert, D., Comer, R., Davis, P., Graham, T., Hewitt, H. T., Hill, R., Hyder, P., Ineson, S., Johns, T. C., Keen, A. B., Lee, R. W., Megann, A., Milton, S. F., Rae, J. G. L., Roberts, M. J., Scaife, A. A., Schiemann, R., Storkey, D., Thorpe, L., Watterson, I. G., Walters, D. N., West, A., Wood, R. A., Woollings, T., and Xavier, P. K.: The Met Office Global Coupled Model 3.0 and 3.1 (GC3.0 \& GC3.1) Configurations, J. Adv. Model. Earth Sy., 10, 357-380, https://doi.org/10.1002/2017MS001115, 2018.

Wu, T., Song, L., Li, W., Wang, Z., Zhang, H., Xin, X., Zhang, Y., Zhang, L., Li, J., Wu, F., Liu, Y., Zhang, F., Shi, X., Chu, M., Zhang, J., Fang, Y., Wang, F., Lu, Y., Liu, X., Wei, M., Liu, Q., Zhou, W., Dong, M., Zhao, Q., Ji, J., Li, L., and Zhou, M.: An overview of BCC climate system model development and application for climate change studies, J. Meteorol. Res., 28, 34-56, https://doi.org/10.1007/s13351-014-3041-7, 2014. 